\title{
The Concept of Landscape Structure, Forest Continuum and Connectivity as a Support in Urban Forest Management and Landscape Planning
}

\author{
Janez Pirnat ${ }^{(D)}$ and David Hladnik* \\ Biotechnical Faculty, University of Ljubljana, 1000 Ljubljana, Slovenia; janez.pirnat@bf.uni-lj.si \\ * Correspondence: david.hladnik@bf.uni-lj.si; Tel.: +386-1-320-3525
}

Received: 27 August 2018; Accepted: 18 September 2018; Published: 20 September 2018

\begin{abstract}
Close-to-nature urban forests and remnants of natural vegetation represent an important opportunity for urban residents to experience daily perception of and access to the natural environment. Despite there being a high percentage of forest cover (59\%) and a favorable structure of the prevailing forested landscapes in Slovenia, urban expansion and infrastructure-driven development has severely weakened the connectivity and conservation of urban and suburban forests. The majority of urban settlements lie within walking distance of the surrounding forests $(<1 \mathrm{~km})$. However, only close-to-nature forests with relatively low silvicultural inputs offer ecosystem services sufficient to fulfil the supply and demand of the expanding urban population. In order to estimate the conservation of forests in the open space of Slovenian settlements, we used a spatial model of landscape structure and forest connectivity. The model can be enhanced with patterns of corridors and stepping stones of natural vegetation in the landscape matrix to provide support in the decision-making process of landscape planning and the conservation of urban and suburban forests.
\end{abstract}

Keywords: urban expansion; landscape structure; spatial model; conservation of forests

\section{Introduction}

The process of urban expansion and infrastructure-driven development is affecting cultural landscapes worldwide [1,2]. This is done at the scale of megacity expansions [3] due to growing urban environments as there are an increasing number of households and demand for larger living spaces [4]. According to the research programme presented in the Atlas of Urban Expansion [1], only $30 \%$ of the world's population inhabited cities in 1950, whereas in 2015 the share increased to $54 \%$ and is expected to reach $66 \%$ by 2050 [5]. In addition, it was emphasized that cities grew faster than the number of their inhabitants, as economic development results in larger average incomes, contributing to a greater consumption of goods and services in general, as well as to increased land consumption per capita.

Securing adequate surfaces for public works and open spaces in advance of development requires concerted public action. According to Ahern [6], landscape ecologists can provide an important contribution to urban planning and design. He proposed strategies to build urban resilience capacity and transdisciplinary collaboration by protecting biodiversity, building urban ecological networks, managing connectivity, planning and designing multifunctionality, as well as practicing redundancy, modularization, and adaptive design. The importance of connectivity and landscape conservation on different scales has been addressed by several authors [7-11].

Hladnik and Pirnat [12] proposed similar methods of applying landscape ecology and urban forestry to an urban environment of predominately forested landscapes. They presented a concept of a stable ecosystem in the form of a forest, combining nature preservation efforts with the primarily social needs of urban society often living in proximity to such natural environments. Connecting the 
human need to experience the natural environment with a life-support system of a persistent forest ecosystem should become an important contribution of urban forestry to the well-being of urban society. The study of urban and peri-urban landscape structures and connectivity should not be used as the sole source of design information, but rather as a method of facilitating and communicating the design process intended to optimize benefits and minimize potential deleterious impacts [13].

The primary function of spatial models is to find alternative solutions to assist land use planning. They are used to conduct surveys of development possibilities at the landscape level and propose solutions for the preservation of the elements of the structure of the landscape, contributing to the cultural landscape's identity and/or biodiversity [14-16]. The importance of such landscape elements can be established at the local scale by analyzing the spatial models of landscape structure and function. In addition, spatial models are becoming increasingly useful in ecological impact assessments and are capable of utilizing the integrated knowledge of different disciplines (and experts) in a clear, reproducible way [17]. In some cases, landscape typology can support the building of spatial models at the local scale [18]. Consequently, spatial models are arguably the most efficient and objective tools for the evaluation of different scenarios.

As has been confirmed by the studies conducted in model areas within different Slovene regions [19-21], the regional scale is too unreliable for the assessment of differences in landscape structure [22]. Changing the scale reveals new spatial patterns, resulting in high variability within statistical regions and a less efficient stratification process. Consequently, the assessment of landscape structure requires the use of several indices adapted for different observation scales [8,23]. Spatial fragmentation indices, for example, have been included in the estimation process of traffic network and regional planning in Europe [24,25].

At the regional scale, evaluating landscape structure and processes is not sufficiently reliable if based solely on the share and prevalence of certain land use types. In fact, it is impossible to build a general spatial model that could provide a solid basis for the assessment of natural processes in a cultural landscape. The stability of forest patches, hedgerows, remnants of former natural vegetation, and all the processes sustained by these landscape elements are further affected by human corridors, urban centers, and smaller, scattered settlements. In open-space areas, efforts toward sustaining landscape structure enable the preservation of natural processes in changing cultural landscapes. Natural processes suffer from the negative impact of human corridors and urbanization, especially along the most-travelled roads [24,26]. Despite being small in size, Slovenia is affected by two processes that endanger its cultural landscape. One is the ongoing abandonment of land use for agricultural purposes, which poses difficulties for the preservation of the characteristic features typical of the present cultural landscape, especially in the prevailing forested landscapes. The other refers to the continued globalization trends in urbanization and agriculture, affecting the structure of urban and agricultural landscapes more than ever before. Due to a small number of people inhabiting the largest Slovenian cities, it is difficult to directly compare urbanization processes and the significance of urban forestry in urban and peri-urban areas with other European countries. In total, the 30 largest Slovenian cities are inhabited by 737,000 people, or $36 \%$ of the entire country's population $[27,28]$. Only the five largest Slovenian cities belong to the category with more than 25,000 inhabitants. In contrast to the countries facing rapid urbanization, Slovenia is characterized by suburbanization and a comparably low share of city inhabitants. The share of the urban population has not exceeded 50\% since 1980s [28]. More suitable than the demographic indices only presenting the spatial observation scale are the landscape ecology indices, which can be used to emphasize the significance of urban forestry. We stressed their importance previously when we analyzed the green areas in the city of Ljubljana [12] and monitored the connectivity of the peri-urban forests [13] influenced by the urbanization processes typical of European cities. In previous research [12] regarding an estimation of the forest continuum based on the close-to-nature tree structure and stability of forest stands, urban forestry was recognized as a branch responsible for the preservation and maintenance of green urban areas and their diversity. The preservation of extensive and undamaged natural habitats 
is typically seen as the most important condition of biodiversity preservation [29]. In agricultural landscapes, the most important factors in biodiversity establishment are natural and semi-natural habitats and their location. It has been established that the nature of the matrix can significantly influence the habitat use by different species, especially in highly fragmented urban and agricultural areas of different countries [30]. However, maintaining biodiversity of urban forests, even in the persistent forest areas, may prove more difficult in the future. Studies have shown that in the majority of European urban areas, woodlands are gradually being fragmented and thinned and urban forests are mostly in decline [31].

Even in the areas assessed with a favorable preservation state regarding potential natural vegetation, humans have influenced their development processes through millennia [32], changing the species composition and fine-grained structure of the forest stands. Despite much debate around whether, in the present day, natural forests still exist at all [32,33], as all the Earth's forests are exposed to direct or indirect human impact, the gradient of naturalness is still evident and might be linked to the formation of the forests' biodiversity [34]. However, as emphasized in a recent proposal for the conservation of biodiversity and sustainable management of forest habitat types, the status of forest vegetation cannot be considered static [35]. One of the most important requirements of urban forest stands is to maintain a high share of trees and other species that would appear on their sites naturally. To preserve the stand's structure, it is necessary to closely monitor its status and assess vulnerability of the most endangered lowland and sub-montane forests containing a disproportionately high share of Norway spruce. As it was determined, lowland forests dominated by spruce require relatively high amounts of direct artificial energy inputs annually, especially in the form of silvicultural and protective measures [36]. Spruce forest stands typically expand into the land closest to farms and settlements along valleys, which explains why they have been so heavily modified by management practices through history. In recent years, these forests have suffered severely from barkbeetle attacks. Consequently, forestry is facing a serious problem, especially as, on the one hand, spruce-dominated forests require high-energy inputs for maintenance and protection, while on the other, these requirements need to be balanced with the pressure of the urban need for multifunctionality at the same level as close-to-nature broadleaved stands. When developing new adapted silvicultural models needed in urban and peri-urban forestry, it is important to share the knowledge stemming from different forest management and silvicultural practices.

The goal of this study is to determine landscape structure and forest connectivity in the urban and peri-urban areas of Slovenia's largest cities. We will present the spatial model based on landscape typification, forest connectivity estimation, and forest continuum in the urban areas that will enable the maintenance or complement the network of forest patches and other green surfaces within cities. Another purpose of the presented article is to provide practical guidelines offering assistance in the decision-making processes regarding possible future forest-clearings caused by the expansion of cities, road and railway infrastructure, or intensification of agricultural areas. To that end, we have taken into consideration recent research studies [37,38], as well as concerns expressed by other researches regarding difficulties emerging from the fragmentation of peri-urban areas $[39,40]$. Using the information at our disposal, we intend to design a spatial model capable of providing a solid basis to assist in the forest management process, while considering the impact of close-to-nature structures on biodiversity as well as attending to the human needs of recreation, health, and well-being.

\section{Materials and Methods}

The concept of the assessment and monitoring of landscape structures aligned with the European Union's (EU) hierarchical territorial system-the Nomenclature of territorial units for statistics (NUTS). The hierarchical system was established for dividing up the territory of the EU for the purpose of collecting regional statistics, conducting socioeconomic analyses of the regions, and the framing of policies [41]. The regional typologies applied to the level 3 NUTS regions were mainly used to monitor rural and urban development, maritime economy, and development of metropolitan regions. 
The system used in the study provides the first accurate measurement of landscape fragmentation for the majority of the European continent intended to support managers and policy-makers in allocating resources towards the protection and restoration of biodiversity and landscape quality [24].

According to the NUTS-3 territorial system, Slovenia is divided into 12 statistical regions [27]. For the purposes of our research, we referred to the collection of data in Slovenian cities [42] to select the 30 largest urban centers distributed throughout the country so that all NUTS-3 statistical units were represented in the study (Figure 1).

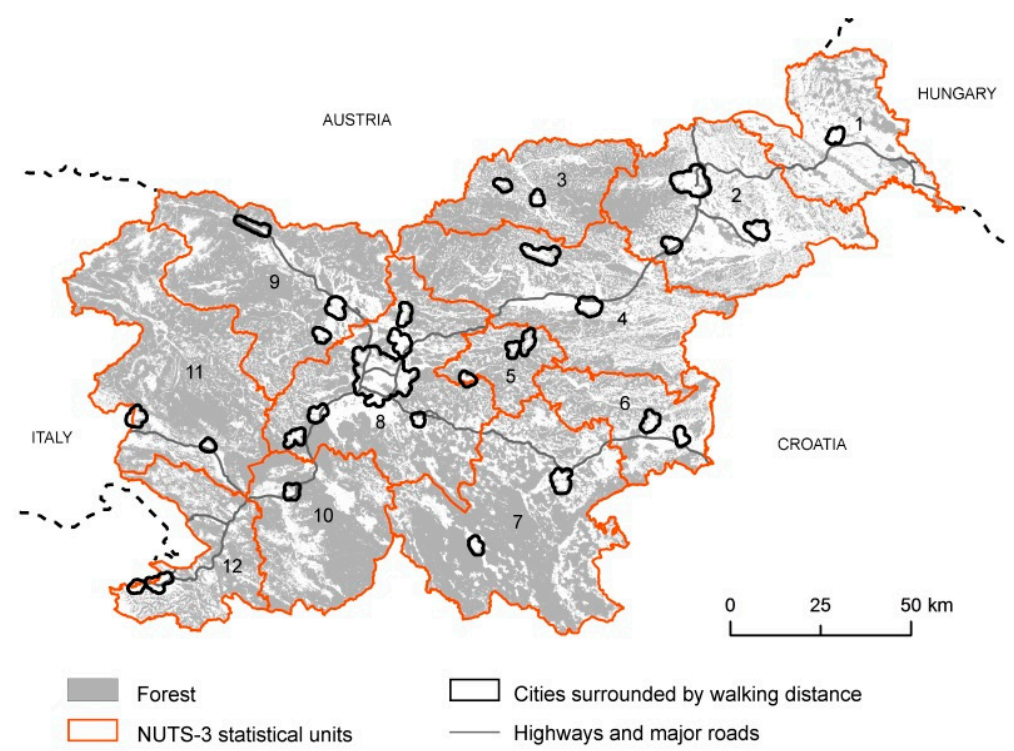

Figure 1. Slovenia divided into NUTS-3 (Nomenclature of territorial units for statistics-3) statistical units with the largest cities, surrounded by a delineated area of a $1 \mathrm{~km}$ walking distance from the built-up areas. Forest patches are fragmented by highways and major roads.

The selected urban areas were studied based on the CORINE Land Cover map [43]. Their landscape structure was analyzed within a $1 \mathrm{~km}$ buffer distance around each city, representing the estimated walking distance from the built-up areas and designating an accessible open space for daily recreation $[12,44,45]$.

For assessment of the typification of the statistical regions and peri-urban areas, we relied on the data on agricultural landscapes [37] with regard to the updated forest map, functional connectivity of forest surfaces, and influence of the extensive corridors. The control layer was comprised of the data on the typification of Slovenia [46]. The connectivity and value of natural vegetation remnants were estimated based on a current land use map of Slovenia, namely an agricultural land use map provided by the Slovenian Ministry of Agriculture, Forestry, and Food [47]. Additional data was collected from the Slovenia Forestry Service's forest stand map [48] with a scale of 1:5000 and a minimum mapping unit of 0.25 ha. This mapping unit is based both on mapping methodology and close-to-nature forest management guiding principles for temperate Central European forests, where for the collective recruitment of forest trees, regeneration gaps of more than $500 \mathrm{~m}^{2}$ are suggested. In order to ensure adequate stability and potential for qualitative selection of light-demanding species, a target gap size of at least 0.25 ha at the start of regeneration and 0.5 ha at the pole stage is recommended [49].

According to the Rules on the Records of Actual Arable and Forest Land Use [50] the data on a forest from the records of actual use may deviate from the forest edge under the forest management plan by a maximum of $15 \mathrm{~m}$. In order to diminish the inconsistencies in estimating spatial forest characteristics in Slovenia, forest edges were expanded through morphological filtering so that all non-forest patches, as well as road and railway networks narrower than $20 \mathrm{~m}$, were removed from the spatial model of the forest areas. Next, we utilized the categorization and the data on the public road and railway network [51,52] to achieve a unified assessment of the dispersion and fragmentation 
of forest areas at the national scale. Public roads (main and regional) and railways were designated an influence zone and buffered by $5 \mathrm{~m}$ on either side of their axis, whereas with highways the buffer distance was doubled to $10 \mathrm{~m}$. Local and minor roads were buffered by $2.5 \mathrm{~m}$, which is comparable to the related methods for the assessment of spatial fragmentation [24,25].

Forest areas were classified according to the internationally comparable, unified typology of forest sites [53]. The typology of forest sites provides a starting point for various categorizations of forests [54] and enables a clarification of differences between them that play an important role in various processes, such as forest management, silvicultural planning, and the assessment of the productivity and floristic similarity of forest sites. In the frame of the Pan-European indicators of sustainable forest management [55], it is defined that reports on the surface and structure of forests are to be made at the level of forest types. In the beginning, these forest types were only referred to as deciduous, coniferous, and mixed. However, following the year 2007, a more in-depth classification of forest types was suggested [54,56]. Due to the typology's hierarchical design and the possibility to merge site types according to different scales of ecological and vegetation factors [53], we used it for the assessment of forest surfaces according to forest type, spatial patterns, and landscape indices, based on which it is also possible to draw conclusions regarding the sustainable management of forests and forest areas.

The naturalness of actual tree species composition was estimated as the deviation of the actual tree species composition from the potential natural vegetation model. The model had previously been employed for defining Slovenia's Natura 2000 forest habitat types [57]. Based on the Forest Vegetation Map of Slovenia [58], it is used in Slovenian forest management.

The forest continuum in the selected urban areas was estimated separately, based on the oldest cartographic sources from the end of the 18th century (military maps of the Austrian Emperor Joseph II, designed between 1763 and 1787) and the later Franciscean cadaster from 1820 [59].

\section{Results}

Slovenian statistical regions significantly differ from each other in the share of agricultural landscapes in the area. Actual agricultural landscapes are prevalent only in two statistical regions of north-east Slovenia (the statistical regions of Mura and Drava). Everywhere else, predominant land use favors the forest, which is additionally supported by the prevailing landscape type. Similar information can be inferred from the number of extensive agricultural landscapes, which are also prevalent only in the two above-mentioned statistical regions (Table 1).

Table 1. Estimations of landscape structure in the statistical regions of Slovenia.

\begin{tabular}{|c|c|c|c|c|c|c|}
\hline \multirow{2}{*}{$\begin{array}{c}\text { Name of Region } \\
\text { in Slovene }\end{array}$} & \multirow{2}{*}{$\begin{array}{l}\text { Area } \\
\left(\mathrm{km}^{2}\right)\end{array}$} & \multirow{2}{*}{$\begin{array}{l}\text { Landscape } \\
\text { Type (LT) }^{1}\end{array}$} & \multirow{2}{*}{$\begin{array}{c}\text { Share }^{2} \\
(\%)\end{array}$} & \multicolumn{3}{|c|}{ And Number of Agricultural LT } \\
\hline & & & & Large $^{3}$ & Medium $^{4}$ & Small $^{5}$ \\
\hline 1. Pomurska & 1337.05 & Agricultural (Agr) & 99.3 & 6 & 1 & 2 \\
\hline 2. Podravska & 217.16 & Agricultural & 72.2 & 7 & 3 & 3 \\
\hline 3. Koroška & 1040.80 & Forested (For) & 8.3 & 0 & 1 & 2 \\
\hline 4. Savinjska & 2299.74 & For/Agr & 36.2 & 5 & 4 & 7 \\
\hline 5. Zasavska & 490.01 & Forested & 4.7 & 1 & 0 & 3 \\
\hline 6. Posavska & 967.60 & For/Agr & 46.2 & 4 & 1 & 4 \\
\hline 7. JV Slovenija & 2670.19 & For/Agr & 22.4 & 1 & 8 & 4 \\
\hline 8. Osrednjeslovenska & 2333.89 & For / Agr & 30.8 & 3 & 5 & 15 \\
\hline 9. Gorenjska & 2136.60 & Forested & 14.4 & 1 & 2 & 6 \\
\hline 10. Primorsko-notranjska & 1456.34 & For/Agr & 20.8 & 1 & 3 & 5 \\
\hline 11. Goriška & 2324.71 & For/Agr & 10.4 & 0 & 5 & 4 \\
\hline 12. Obalno kraška & 1044.36 & For/Agr & 31.5 & 1 & 1 & 8 \\
\hline
\end{tabular}


By taking a closer look at the 30 largest Slovenian cities, we were interested in establishing the characteristics of the landscapes they lay in and the forests that encircled them. Based on data on the forest cover of Slovenia, we used the GIS ArcMap10.4 (Redlands, CA, USA) [60] environment to assess the forest structure and its primeval nature within patches/matrices within a $1 \mathrm{~km}$ radius around the selected cities. A patch is a clearly separated forest surface encircled by another type of land use, while a matrix consists of a forest that continues uninterrupted beyond the designated $1 \mathrm{~km}$ radius until it reaches the background of the study area. Most of the selected cities predominantly lay within one landscape type. One exception is Ptuj, which lies at the juncture of three landscape types, with its forest-cover estimation consequently being presented within range. In addition to estimating the forest cover and landscape type of the areas in which the cities are located, we analyzed the forest surface and structure within a $1 \mathrm{~km}$ radius around each of them. The results are listed in Table 2 and presented in Figure 2.

Table 2. Landscape indices and primeval structure of forests surrounding the largest Slovenian cities.

\begin{tabular}{|c|c|c|c|c|c|c|c|c|c|c|c|c|}
\hline Code & City & $\begin{array}{l}\text { Area } \\
\left(\mathrm{km}^{2}\right)\end{array}$ & $\begin{array}{l}\operatorname{Inh}^{1} \\
(1000)\end{array}$ & $\begin{array}{c}\text { Landscape } \\
\text { Type }^{2}\end{array}$ & $\begin{array}{c}\mathrm{FC}^{3} \\
(\%)\end{array}$ & $\begin{array}{l}\text { FA }^{4} \\
\left(\mathrm{~km}^{2}\right)\end{array}$ & $\begin{array}{c}\mathrm{LM}^{5} \\
(\%)\end{array}$ & $\begin{array}{l}\text { LP } 6 \\
(\%)\end{array}$ & FST $^{7}$ & $\begin{array}{l}\mathrm{CT}^{8} \\
(\%)\end{array}$ & $\begin{array}{c}\mathrm{CH}^{9} \\
(\%)\end{array}$ & $\begin{array}{c}\mathrm{SC}^{10} \\
(\%)\end{array}$ \\
\hline 1 & Murska Sobota & 4.00 & 11.6 & L Agr & 15 & 1.14 & 0 & 100 & 53 & 88 & -12 & 57 \\
\hline 2.1 & Maribor & 24.81 & 95.2 & M Agr/Urb & 10 & 12.65 & 30 & 70 & $71 / 78$ & 83 & -8 & 35 \\
\hline 2.2 & Ptuj & 5.43 & 18.2 & L Agr & $9-34$ & 3.16 & 0 & 100 & $54 / 73$ & 67 & -2 & 17 \\
\hline 2.3 & Slov. Bistrica & 3.47 & 7.4 & L Agr & 29 & 3.95 & 61 & 39 & 54 & 89 & -9 & 30 \\
\hline 3.1 & Ravne & 2.08 & 7.0 & S Agr & 22 & 6.56 & 96 & 4 & $77 / 75$ & 78 & +6 & 0 \\
\hline 3.2 & Slov. Gradec & 2.26 & 7.5 & M Agr & 20 & 3.82 & 76 & 24 & $77 / 75$ & 85 & -1 & 39 \\
\hline 4.1 & Celje & 9.76 & 37.5 & $\mathrm{~S}$ Agr/Urb & 2 & 5.50 & 79 & 21 & $74 / 73$ & 84 & -1 & 86 \\
\hline 4.2 & Velenje & 7.40 & 25.5 & M Agr & 26 & 14.19 & 36 & 64 & 73 & 92 & -5 & 49 \\
\hline 5.1 & Zagorje & 1.48 & 6.4 & Forested & 24 & 8.00 & 91 & 9 & $58 / 59$ & 73 & +9 & 88 \\
\hline 5.2 & Trbovlje & 3.39 & 15.2 & S Agr & 24 & 11.55 & 91 & 9 & $75 / 59$ & 69 & +5 & 86 \\
\hline 5.3 & Litija & 1.63 & 6.5 & S Agr & 5 & 6.32 & 99 & 1 & 75 & 84 & +4 & 9 \\
\hline 6.1 & Krško & 4.24 & 7.1 & L Agr & 21 & 7.15 & 81 & 19 & $73 / 55$ & 79 & +1 & 56 \\
\hline 6.2 & Brežice & 2.20 & 6.6 & L Agr & 21 & 1.03 & 28 & 72 & $53 / 55$ & 34 & +3 & 82 \\
\hline 7.1 & Kočevje & 2.58 & 8.7 & L Agr & 4 & 4.00 & 87 & 13 & 64 & 33 & +17 & 41 \\
\hline 7.2 & Novo mesto & 6.51 & 23.3 & L Agr & 29 & 10.65 & 47 & 53 & $55 / 54$ & 77 & +3 & 46 \\
\hline 8.1 & Kamnik & 3.67 & 13.6 & L Agr & 33 & 7.24 & 86 & 14 & $75 / 74$ & 84 & 0 & 16 \\
\hline 8.2 & Mengeš & 1.61 & 6.1 & L Agr & 33 & 1.57 & 98 & 2 & 74 & 80 & +3 & 99 \\
\hline 8.3 & Domžale & 5.09 & 12.4 & L Agr & 33 & 2.33 & 45 & 55 & 74 & 71 & +1 & 16 \\
\hline 8.4 & Ljubljana & 59.76 & 272.2 & L Agr/Urb & 13 & 49.96 & 71 & 29 & $75 / 74$ & 80 & +1 & 66 \\
\hline 8.5 & Grosuplje & 1.68 & 7.1 & M Agr & 9 & 1.98 & 55 & 45 & 55 & 84 & -3 & 12 \\
\hline 8.6 & Vrhnika & 3.14 & 8.4 & S Agr & 8 & 4.15 & 82 & 18 & 55 & 35 & +13 & 49 \\
\hline 8.7 & Logatec & 2.89 & 8.9 & S Agr & 12 & 11.44 & 97 & 3 & 64 & 31 & +35 & 32 \\
\hline 9.1 & Jesenice & 4.83 & 13.4 & S Agr & 10 & 17.57 & 98 & 2 & $63 / 59$ & 71 & +14 & 33 \\
\hline 9.2 & Kranj & 7.55 & 36.9 & M Agr & 43 & 4.92 & 44 & 56 & $71 / 54$ & 47 & +5 & 45 \\
\hline 9.3 & Škofja Loka & 2.17 & 12.0 & M Agr & 20 & 5.61 & 95 & 5 & $55 / 75$ & 92 & -5 & 37 \\
\hline 10 & Postojna & 2.68 & 9.2 & M Agr & 16 & 7.44 & 86 & 14 & $56 / 64$ & 14 & +36 & 32 \\
\hline 11.1 & Ajdovščina & 2.07 & 6.6 & S Agr & 11 & 3.48 & 98 & 2 & 56 & 3 & +28 & 48 \\
\hline 11.2 & Nova Gorica & 5.19 & 13.2 & M Agr & 34 & 7.79 & 95 & 5 & $54 / 56$ & 59 & +10 & 47 \\
\hline 12.1 & Izola & 2.12 & 11.2 & L Agr & 25 & 0.84 & 0 & 100 & 56 & 15 & +5 & 55 \\
\hline 12.2 & Koper & 5.67 & 25.0 & L Agr & 25 & 0.80 & 0 & 100 & 56 & 7 & +2 & 45 \\
\hline
\end{tabular}

${ }^{1}$ Inh-number of inhabitants per city in $1000 ;{ }^{2}$ landscape type in the areas in which the cities are located-Large (L), Medium (M), and Small (S), according to Firm and Pirnat [38]; ${ }^{3}$ FC - forest cover and forest area $\left({ }^{4} \mathrm{FA}\right)$ in the cities and within a $1 \mathrm{~km}$ walking distance around cities; ${ }^{5} \mathrm{LM}$ - share of urban forest area in the forest matrix or in the forest patches $\left({ }^{6} \mathrm{LP}\right) ;{ }^{7} \mathrm{FST}$ - forest site types according to Kutnar et al. [53]; ${ }^{8} \mathrm{CT}$ - share of forest continuum area within a $1 \mathrm{~km}$ walking distance around cities; ${ }^{9} \mathrm{CH}$-changes of forest area in the last 200 years; ${ }^{10} \mathrm{SC}$ - share of forest area with less than $30 \%$ of foreign or non-indigenous tree species, according to the Slovenia Forest Service [58]. On the carbonate and mixed carbonate-silicate rocks: 53-Forests of Quercus robur L. and Carpinus betulus L.; 54-Forests of Carpinus betulus L., and of Quercus petraea (Matt.) Liebl.; 55-Submontane Fagus sylvatica L. forests; 56-Forests and woodlands of thermop. Broadleaves; 58-Fagus sylvatica L. forests in shady sites; 59-Thermophilous Fagus sylvatica L. forests; 63-Montane Fagus sylvatica L. forests; On the silicate rocks: 71-Forests of Carpinus betulus L. with Quercus p.; 73-Submontane Fagus sylvatica L. forests; 74-Acidophilous Pinus sylvestris L. forests; 75-Submontane Fagus sylvatica L. forests; 77-Forests of Abies alba Mill., and of Picea abies (L.) H. Karst; 78-Montane Fagus sylvatica L. forests; 64-Forests of Fagus sylvatica L. with Abies alba Mill. 

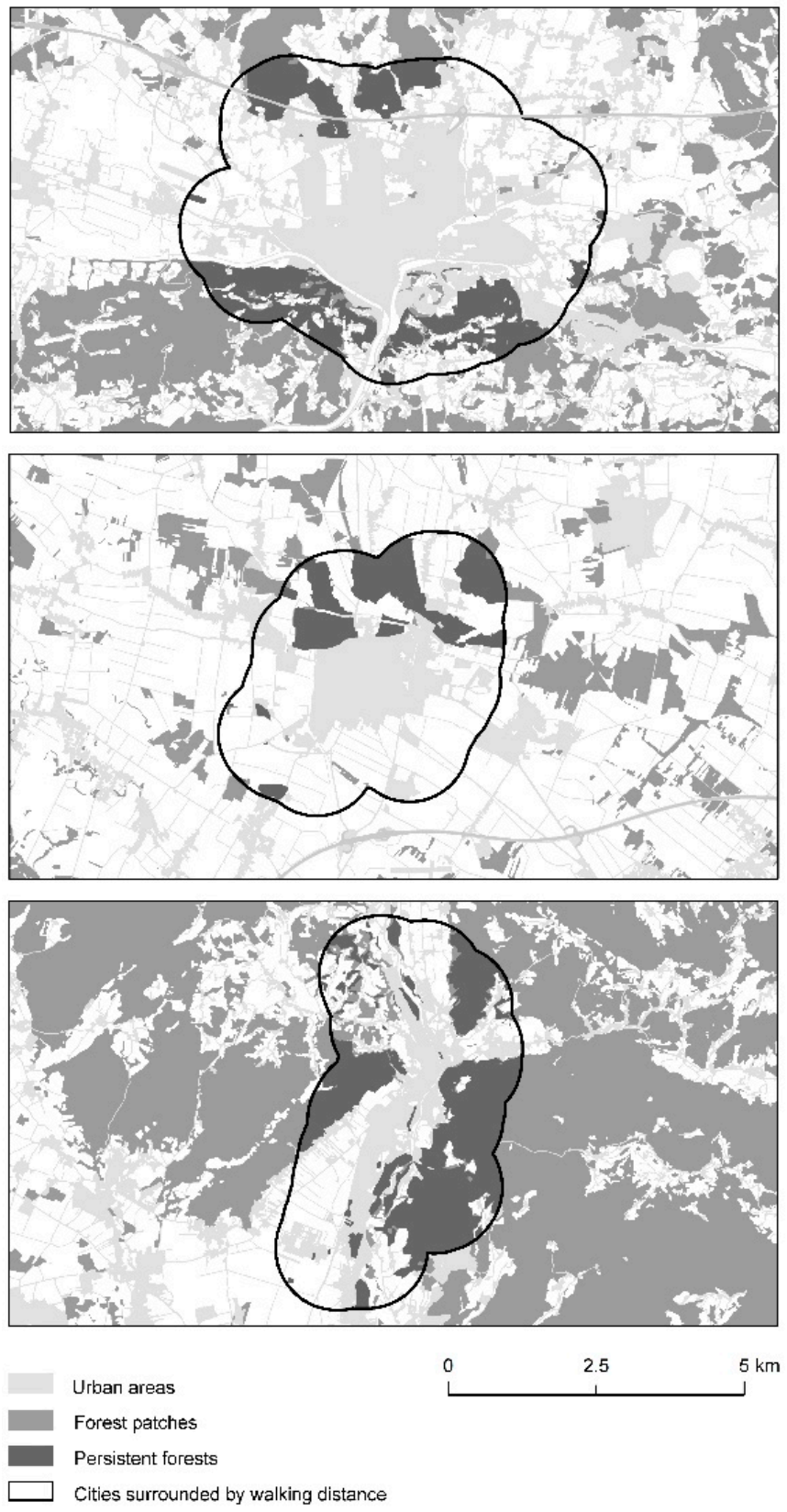

Figure 2. Maps of the selected study areas (Celje, Murska Sobota, Kamnik) with urban areas and forest patches. Cities are surrounded by a delineated area of a $1 \mathrm{~km}$ walking distance from the built-up area. Persistent forests represent the continuum of the natural environment in a $1 \mathrm{~km}$ walking distance area of the cities.

While the surrounding forest cover of the cities situated in so-called small agricultural landscapes can be relatively small-sometimes even less than 10\% (e.g., Celje, Litija, Kočevje, Grosuplje, Vrhnika) -forests falling within the radius belong predominantly to the forest matrix, which indicates the special position of the abovementioned cities. They are situated on a flat surface, and the agricultural landscape in their vicinity is relatively simply rounded. However, not far from the edge of the cities, the flat surface gives way to a hilly landscape unsuitable for agricultural purposes and consequently covered with forests. These forests both lie close to the cities and form a forest matrix. They are interesting not only because of their recreational and diversity functions, but also because they are usually well-preserved and have a high share of primeval structure $[12,13,38]$. 
The second group is comprised of cities situated mostly in large agricultural landscapes, with a forest cover of above $10 \%$ to as much as $25 \%$-however, all the forests are distributed in the shape of patches (Murska Sobota, Ptuj, Izola, Koper). Murska Sobota and Ptuj lie in the most agricultural part of Slovenia, where forest patches function as so-called stepping stones and have an emphasized diversity and climate function as well as a recreational function due to their proximity to urban areas. Izola and Koper lie on the Slovenian shore in a Mediterranean landscape, where forest is scarce and pushed to less favorable surfaces in order to make way for human settlements, but retains its diversity, climate, protection, and recreational functions.

The third group includes cities with an elongated, even amoeboid shape, resulting in a relatively high forest cover in their vicinity [37] as they stretch across a prolonged surface (Domžale, Kamnik, Velenje, Trbovlje). Again, these cities are typically situated in lowland areas, but come very close to the hilly forested landscape with an emphasized recreational, diversity, and climate function.

Due to the position of the cities in the landscape, the forest cover within a $1 \mathrm{~km}$ radius, also regarded as the approximate walking distance of the inhabitants, was mostly increasing over the last 200 years (Table 2). Cities usually expanded at the cost of agricultural land, and more rarely, urbanization processes included clearing a high share of forest land (e.g., Murska Sobota, Maribor, Slovenska Bistrica, Ptuj, Grosuple, Škofja Loka). Based on the comparison between land uses registered in the Franciscean cadaster from the beginning of the 18th century and the current forest expansion in this peri-urban area, we estimated a high share of primeval or persistent forest land. In 20 out of 30 analyzed largest Slovenian cities, the share of such land even exceeds two thirds.

Preservation of the species structure in these forests is favorable as well (the share of foreign or non-indigenous tree species is less than 30\%), even though the geographically small space is intertwined with forest sites ranging from thermophilic deciduous forests (forests and woodlands of thermophilous broadleaves) in the area of the coastal cities (Izola, Koper) to montane beech forests (Jesenice, Maribor). In the vicinity of the cities otherwise situated in extensive agricultural landscapes (Murska Sobota, Brežice), we even estimated the remains of lowland floodplain forests (forests of Quercus robur L. and Carpinus betulus L.), a rare occurrence in Slovenia-as well as other European countries. In nine of the analyzed areas, the mapping of potential natural vegetation and the comparison with the current species structure of forests have shown the predominance of a favorable species structure in more than half of the forest sites. In the vicinity of 13 cities, forest stands with a well-preserved species structure encompassed at least one third of the forest sites.

\section{Discussion}

Analyses of landscape structure and fragmentation due to urban development, land-use changes, and transportation infrastructure can provide information and practical guidelines to be included in land-use planning and decision-making processes in an ecologically meaningful way. According to a comparative study of 15 European urban landscapes, the increase in the built-up areas over the last 50 years have primarily enfolded the formerly agricultural land [61], similar to the results of our study (Table 2). Typically, agricultural land was better suited for construction than forest surfaces were, while the natural areas were protected against urbanization. One half of the analyzed European urban landscapes [61] displayed an over 90\% high share of discontinuous and dispersed new housing areas experiencing urban sprawl. Urban development dispersed in this way may have a strong impact on the connectivity of forests and natural areas even though it may not significantly change them in size.

In addition to urban areas of the largest European cities (over 450,000 inhabitants) and capital cities [4,61], the intense urbanization was identified as the driving force of landscape change in the high-value landscapes, where new built-up areas have mainly been acquired at the expense of arable land [62]. The scale of the urban population was similar to our study, predominantly encompassing the cities with less than 15,000 inhabitants. Despite traditionally scattered settlements and the development of larger urban centers along highways, the majority of the largest Slovenian cities are surrounded by forested matrix. In the last 200 years, a decrease in forest cover and increased fragmentation of forest 
patches were the most distinct in the north-eastern part of Slovenia, where large agricultural landscape types prevail (Table 1). In most of the suburban areas and agricultural landscapes, the pressure of urbanization and infrastructure on forest space was less profound. The results confirm the findings based on effective mesh size landscape metrics. Most of the urbanization and associated fragmentation due to transportation is located in the lower elevation valleys, where agricultural areas are covered by a dense network of minor roads [24,25].

In the last decade, the urbanization process in Slovenia was most strongly affected by the construction of the highway network (Figure 1) and the expansion of commercial and industrial centers in peri-urban areas [28,63]. As presented in a study of 202 European cities [4], residential urban areas seem to increase regardless of population changes. This can be attributed to a growing number of households demanding larger living spaces. The role of urban nature and urban green infrastructure has become important to dwellers of the contemporary urban society [64], where citizens derive physical and mental health benefits and other "ecosystem services" from urban and suburban green areas.

In spite of the high amount and official integration of green areas in the Slovenian urban-planning documents, their natural assets were not optimally utilized. In the city of Ljubljana, the connectivity changes and loss thereof during two different periods between 1975 and 2012 were presented with a spatial model [13], intended to assist landscape planners in identifying and analyzing the critical elements of the changing landscape. Considering the small number of forest clearances conducted in the last decade, it is imperative that the urbanization processes influencing the suburban environment identify critical points in space that are crucial for the preservation of connectivity in urban and suburban forests. These changes result in an increasing demand for new knowledge on forest structure and ecosystem services, as well as new challenges for the scientific community to analyse the data and synthesize knowledge, informing decision-making on governmental and non-governmental levels. Our study presents a methodological framework to be used in the assessment of the forest continuum and preservation of urban forests with close-to-nature tree composition. Since these forests differ in species composition and ecological conditions, we propose the estimation of their conservation status and proper management regimes based on forest site typology [53].

In the majority of the European states, the typology of forest sites became a starting point for the stratification of forest surfaces into smaller, ecologically more homogenous units, enabling easier analysis, interpretation, and presentation of the characteristics of the forests and providing us with invaluable data, especially regarding their biotic diversity [65]. As in larger countries [66], it is unlikely that in Slovenia, geographically equipped stratification processes at the regional scale could efficiently substitute detailed land-use mapping. The shares of unexplained variation in the estimation of forest cover and other prevalent land use in Slovenia exhibit high variability within statistical regions, as well as spatial units formed on the basis of different typology groups of forest stands [22].

However, in the last decade, detailed land use and land cover mapping contributed to the development of numerous concepts of monitoring and sample evaluation of landscape structure, variety, and changes that exceed the mere collection of data from land use records [67-69]. Much like in the other countries [70,71], where conditions and changes are assessed within sampling blocks or kilometer-large squares, intensive work in the sampling areas ensures higher accuracy, especially concerning the comparability of land use data in different time periods. Up until now, the Slovenian methodology of selection and defining categories of land use was adjusted to the measures of the EU's common agricultural policy, and as a result, the data obtained in the last decade could not be directly applied to the analyses of land-use changes [72]. Based on the acquitted data, however, it is now possible to build spatial models and establish the concepts of landscape structure and the preservation of connectivity between forest patches of urban and suburban forests in order to support the conservation of biodiversity and the adaptation of the local environment to climate change, promoting the green economy and increasing social cohesion for the well-being of the general populace. Such a development is strongly recommended for mutual responsibility and cooperation 
between the governmental and non-governmental sectors in urban green space planning, governance, and management in order to avoid the shortcomings of the instrumental top-down planning processes.

\section{Conclusions}

The intent of the presented landscape typification and forest continuum estimation in urban and peri-urban landscapes was to demonstrate the landscape ecological reference points regarded as a considerable step forward to offering urban forestry an alternative active role in shaping urban green spaces and to preserve persistent urban and suburban forests. Based on the analysis of the 30 largest Slovenian cities, we determined that the majority of them are still surrounded by forested matrix. The methodology adopted in the present study allowed us to determine and quantify persistent forests located within urban and peri-urban landscapes to enable the inhabitants daily access to the pristine natural environment.

Over the last 200 years, cities usually expanded at the cost of agricultural land-and more rarely, urbanization processes included clearing a high share of forest land. Despite the favorable spatial distribution of forests in urban and peri-urban areas, it is important to recognize the contribution of individual forest areas to the overall landscape connectivity and the biotic value of preserved forest-stand composition, which would protect them from land-use changes.

The present study suggests that nature preservation and connectivity changes in the landscape can be presented by a spatial model based on the analysis of the continuum of the forests, share of preserved tree-species' composition, and the spatial position of forests in the landscape structure. The intention of the model is to support decision-making in landscape-planning and conservation of the natural environment, and also to support forest ecosystem services in urban and peri-urban landscapes. Therefore, we propose the following practical guidelines for decision-making processes in urban forests:

(1) The preservation of urban forests with close-to-nature tree composition;

(2) The preservation of older urban forests;

(3) The preservation of areas with persistent forest cover;

(4) The preservation of green infrastructure networks, supporting connectivity between urban forests and sub-urban green areas.

In this way, we are co-building governance approaches so that they are sustainable and can support present and future ecosystem services for environmental circumstances that are unpredictable and uncertain. Such an understanding of urban forestry can help to mobilize social capital in urban and suburban green areas.

Author Contributions: Conceptualization, J.P. and D.H.; methodology, D.H.; validation, D.H., J.P.; formal analysis, J.P. and D.H.; investigation, J.P. and D.H.; resources, D.H. and J.P.; data curation, D.H.; writing-original draft preparation, J.P. and D.H.; writing-review and editing, D.H.

Funding: This research was funded by Slovenian Research Agency (ARRS) through financing of the programme group Forest, forestry and renewable forest resources and by Pahernik Foundation.

Conflicts of Interest: The authors declare no conflict of interest. The funders had no role in the design of the study; in the collection, analyses, or interpretation of data; in the writing of the manuscript, or in the decision to publish the results.

\section{References}

1. Angel, S.; Blei, A.M.; Parent, J.; Lamson-Hall, P.; Sánchez, N.G.; Civco, D.L.; Qian Lei, R.; Thom, K. Areas and Densities. In Atlas of Urban Expansion-2016 Edition; NYU Urban Expansion Program at New York University, UN-Habitat, and the Lincoln Institute of Land Policy: New York, NY, USA, 2016; Volume 1, p. 489, ISBN 978-970-9981758-0-5.

2. Wang, Z. Evolving landscape-urbanization relationships in contemporary China. Landsc. Urban Plan. 2018, 171, 30-41. [CrossRef] 
3. Kuang, W.; Chi, W.; Lu, D.; Doue, Y. A comparative analysis of megacity expansions in China and the U.S.: Patterns, rates and driving forces. Landsc. Urban Plan. 2014, 132, 121-135. [CrossRef]

4. Kabisch, N.; Haase, D. Green spaces of European cities revisited for 1990-2006. Landsc. Urban Plan. 2013, 110, 113-122. [CrossRef]

5. UN Habitat. Urbanization and Development: Emerging Futures; World Cities Report; United Nations Human Settlements Programme: Nairobi, Kenya, 2016; p. 247.

6. Ahern, J. Urban landscape sustainability and resilience: The promise and challenges of integrating ecology with urban planning and design. Landsc. Ecol. 2012, 28, 6. [CrossRef]

7. Pascual-Hortal, L.; Saura, S. Comparison and development of new graph-based landscape connectivity indices: Towards the priorization of habitat patches and corridors for conservation. Landsc. Ecol. 2006, 21, 959-967. [CrossRef]

8. Pascual-Hortal, L.; Saura, S. A new habitat availability index to integrate connectivity in landscape conservation planning: Comparison with existing indices and application to a case study. Landsc. Urban Plan. 2007, 83, 91-103. [CrossRef]

9. Saura, S.; Rubio, L. A common currency for the different ways in which patches and links can contribute to habitat availability and connectivity in the landscape. Ecography 2010, 33, 523-537. [CrossRef]

10. Saura, S.; Estreguil, C.; Mouton, C.; Rodriguez-Freire, M. Network analysis to assess landscape connectivity trends; Application to European Forests (1990-2000). Ecol. Indic. 2011, 11, 407-416. [CrossRef]

11. Saura, S.; Vogt, P.; Velázquez, J.; Hernando, A.; Tejera, R. Key structural forest connectors can be identified by combining landscape spatial pattern network analyses. For. Ecol. Manag. 2011, 262, 150-160. [CrossRef]

12. Hladnik, D.; Pirnat, J. Urban forestry-linking naturalness and amenity: The case of Ljubljana, Slovenia. Urban For. Urban Green. 2011, 10, 105-112. [CrossRef]

13. Pirnat, J.; Hladnik, D. Connectivity as a tool in the prioritization and protection of sub-urban forest patches in landscape conservation planning. Landsc. Urban Plan. 2016, 153, 129-139. [CrossRef]

14. Antrop, M.; van Eetvelde, V. Landscape Perspectives: The Holistic Nature of Landscape, 1st ed.; Springer: Dordrecht, The Netherlands, 2017; p. 436, ISBN 978-994-024-1181-1182.

15. Naveh, Z. Interactions of landscapes and cultures. Landsc. Urban Plan. 1995, 32, 43-54. [CrossRef]

16. Pinto-Correia, T.; Primdahl, J.; Pedroli, B. European Landscapes in Transition: Implication for Policy and Practice, 1st ed.; Cambridge University Press: Cambridge, UK, 2018; p. 286, ISBN 978-971-107-07069-07061.

17. Verboom, J.; Wamelink, W. Spatial modeling in landscape ecology. In Issues and Perspectives in Landscape Ecology, 1st ed.; Wiens, J.A., Moss, M.R., Eds.; Cambridge Univeristy Press: Cambridge, UK, 2005; pp. 79-89, ISBN 978-970-521-53754-53751.

18. Solecka, I.; Raszka, B.; Krajewski, P. Landscape analysis for sustainable land use policy: A case study in the municipality of Popielów, Poland. Land Use Policy 2018, 75, 116-126. [CrossRef]

19. Hladnik, D.; Tajnikar, M. Gozdni habitatni tipi območij Natura 2000 v krajinski zgradbi Pohorja. Zbornik Gozdarstva in Lesarstva 2008, 87, 15-32.

20. Pirnat, J.; Kobler, A. Landscape changes in the Pivka area, Slovenia. Zbornik Gozdarstva in Lesarstva 2012, 98, 39-49.

21. Pirnat, J.; Kobler, A. Stabilnost gozdnih površin v Sloveniji kot kriterij krajinske pestrosti in obstojnosti. Acta Silvae et Ligni 2014, 104, 35-42. [CrossRef]

22. Hladnik, D. Presoja prostorskega stratificiranja za vzorčno ocenjevanje gozdnih zemljišč. Acta Silvae et Ligni 2015, 108, 19-28.

23. McGarigal, K. Landscape Metrics for Categorical Map Patterns. Lecture Notes. Available online: http: //www.umass.edu/landeco/teaching/landscape_ecology/schedule/chapter9_metrics.pdf (accessed on 3 July 2018).

24. EEA (European Environment Agency). Landscape Fragmentation in Europe; European Environment Agency; Technical Report; EEA (European Environment Agency): Copenhagen, Danmark, 2011; p. 87. ISSN 1725-9177.

25. Girvetz, E.H.; Thorne, J.H.; Berry, A.M.; Jaeger, J.A.G. Integration of landscape fragmentation analysis into regional planning: A statewide multiscale case study from California, USA. Landsc. Urban Plan. 2008, 86, 205-218. [CrossRef]

26. Jongman, R.H.G. Homogenisation and fragmentation of the European landscape: Ecological consequences and solutions. Landsc. Urban Plan. 2001, 58, 211-221. [CrossRef] 
27. Statistical Office of the Republic of Slovenia. Data by Statistical Regions. Available online: http:/ / pxweb. stat.si/pxweb/Database/Regions/Regions.asp (accessed on 26 August 2018).

28. National Report on Urban Developmentm-HABITAT III. Ministry of the Environment and Spatial Planning of the Republic of Slovenia. Spatial Planning, Construction and Housing Directorate. Available online: http:/ / www.mop.gov.si/fileadmin/mop.gov.si/pageuploads/publikacije/en/porocilo_ urbani_razvoj_HabitatIII.pdf (accessed on 26 August 2018).

29. Alvey, A.A. Promoting and preserving biodiversity in the urban forest. Urban For. Urban Green. 2006, 5 , 195-201. [CrossRef]

30. Environment Canada. How Much Habitat is Enough? 3rd ed.; Environment Canada: Toronto, ON, Canada, 2013; p. 130, ISBN 978-1-100-21921-9.

31. Pauleit, S.; Jones, N.; Nyhuus, S.; Pirnat, J.; Salbitano, F. Urban forest resources in European cities. In Urban Forests and Trees, 1st ed.; Konijnendijk, C.C., Nilsson, K., TRandrup, T.B., Schipperijn, J., Eds.; Springer: Berlin, Germany, 2005; pp. 49-80, ISBN 978-3-540-25126-2.

32. Peterken, G.F. Natural Woodland: Ecology and Conservation in Northern Temperate Regions., 1st ed.; Cambridge University Press: Cambridge, UK, 1996; p. 522, ISBN 521-36613-5.

33. Remmert, H. Ökologie: Ein Lehrbuch, 1st ed.; Springer: Berlin/Heidelberg, Germany, 2013; p. 351, ISBN 978-3-540-54732-7.

34. Winter, S.; Fischer, H.S.; Fischer, A. Relative quantitative reference approach for naturalness assessments of forests. For. Ecol. Manag. 2010, 259, 1624-1632. [CrossRef]

35. Kovač, M.; Hladnik, D.; Kutnar, L. Biodiversity in (the Natura 2000) forest habitats is not static: Its conservation calls for an active management approach. J. Nat. Conserv. 2018, 43, 250-260. [CrossRef]

36. Pirnat, J.; Hladnik, D. Artificial energy inputs into spruce lowland forests in suburban landscapes in Slovenia. Zbornik Gozdarstva in Lesarstva 2009, 89, 67-77.

37. Firm, D.; Pirnat, J. Predlog metodologije za razmejevanje kmetijskih in primestnih krajin v Sloveniji ter prostorska določila za določanje gozdov s poudarjeno funkcijo ohranjanja biotske raznovrstnosti. Gozdarski Vestn. 2017, 5, 246-263.

38. Verlič, A.; Arnberger, A.; Japelj, A.; Simončič, P.; Pirnat, J. Perceptions of recreational trail impacts on an urban forest walk: A controlled field experiment. Urban For. Urban Green. 2015, 14, 89-98. [CrossRef]

39. Coulson, R.N.; Tchakerian, M.D. Basic Landscape Ecology; Knowledge Engineering Laboratory Partners, Inc.: College Station, TX, USA, 2010; p. 300, ISBN 978-970-9831617-0-7.

40. Gurevitch, J.; Scheiner, S.M.; Fox, G.A. The Ecology of Plants; Sinauer Associates, Inc., Publishers: Sunderland, MA, USA, 2002; p. 523, ISBN 0-87893-291-7.

41. Regulation (EC) No 1059/2003 of the European Parliament and of the Council on the Establishment of a Common Classification of Territorial Units for Statistics (NUTS). Official Journal of the European Union L 154/1. Available online: http:/ / data.europa.eu/eli/reg/2003/1059/oj (accessed on 13 June 2018).

42. Statistical Office of the Republic of Slovenia. Data on Population of Slovenia by Settlements. Available online: http:/ / www.stat.si/StatWeb/en/Field/Index/20/65 (accessed on 26 August 2018).

43. Copernicus. Copernicus Land Service-Pan-European Component: CORINE Land Cover. Available online: http:/ / land.copernicus.eu/pan-european/corine-land-cover (accessed on 11 July 2018).

44. Hornsten, L.; Fredman, P. On the distance to recreational forests in Sweden. Landsc. Urban Plan. 2000, 51, 1-10. [CrossRef]

45. Arnberger, A. Recreation use of urban forests: An inter-area comparison. Urban For. Urban Green. 2006, 5, 135-144. [CrossRef]

46. Hladnik, D. Spatial structure of disturbed landscapes in Slovenia. Ecol. Eng. 2005, 24, 17-27. [CrossRef]

47. Slovenian Ministry of Agriculture, Forestry and Food. Grafični podatki RABA za celo Slovenijo. Available online: http:/ /rkg.gov.si/GERK/ (accessed on 30 April 2015).

48. Slovenia Forest Service. Forest Stand Map. Available online: http://prostor.zgs.gov.si/pregledovalnik/ (accessed on 26 August 2018).

49. Schuetz, J.-P.; Saniga, M.; Diaci, J.; Vrška, T. Comparing close-to-nature silviculture with processes in pristine forests: Lessons from Central Europe. Ann. For. Sci. 2016, 73, 911-921. [CrossRef]

50. Rules on the Records of Actual Arable Land Use; No 122/80; Official Gazette of the Republic of Slovenia: Ljubljana, Slovenia, 2008. Available online: http:/ / www.pisrs.si/Pis.web/pregledPredpisa?id=PRAV9267 (accessed on 26 August 2018). 
51. Slovenian Infrastructure Agency. Road and Railway Infrastructure. Available online: http:/ /www.mzi.gov.si / si/delovna_podrocja/ceste/drzavne_ceste/\#c10917/zeleznice_in_zicnice/javna_zelezniska_infrastruktura (accessed on 15 October 2015).

52. The Surveying and Mapping Authority of the Republic of Slovenia. Cadastre of Public Infrastructure-Transport Infrastructure. Available online: http:/ / www.e-prostor.gov.si/zbirke-prostorskih-podatkov / zbirni-katastergospodarske-javne-infrastrukture/ (accessed on 26 August 2018).

53. Kutnar, L.; Veselič, Ž.; Dakskobler, I.; Robič, D. Tipologija gozdnih rastišč Slovenije na podlagi ekoloških in vegetacijskih razmer za potrebe usmerjanja razvoja gozdov. Gozdarski Vestn. 2012, 70, 195-214.

54. Barbati, A.; Corona, P.; Marchetti, M. A forest typology for monitoring sustainable forest management: The case of European forest types. Plant Biosyst. 2007, 141, 93-103. [CrossRef]

55. Forest Europe. Improved Pan-European Indicators for Sustainable Forest Management. Ministerial Conference on the Protection of Forests in Europe, Liaison Unit Vienna. Available online: https: / /www. foresteurope.org/documentos/improved_indicators.pdf (accessed on 17 July 2018).

56. Barbati, A.; Marchetti, M.; Chirici, G.; Corona, P. European Forest Types and Forest Europe SFM indicators: Tools for monitoring progress on forest biodiversity conservation. For. Ecol. Manag. 2014, 321, 145-157. [CrossRef]

57. Golob, A. Izhodišča za monitoring ohranjenosti gozdnih habitatnih tipov in habitatov vrst na območjih Natura 2000 v Sloveiji. Studia For. Slov. 2006, 127, 223-246.

58. Slovenia Forest Service. Forest Compartment Database. Available online: http://prostor.zgs.gov.si/ pregledovalnik/ (accessed on 17 July 2018).

59. Mapire. The Historical Map Portal. Available online: http:/ / mapire.eu/en/ (accessed on 06 June 2018).

60. ESRI. ArcGIS Desktop Release 10.4; Environmental Systems Research Institute: Redlands, CA, USA, 2016.

61. Kasanko, M.; Barredo, J.I.; Lavalle, C.; McCormic, N.; Demicheli, L.; Sagris, V.; Brezger, A. Are European cities becoming dispersed? A comparative analysis of 15 European urban areas. Landsc. Urban Plan. 2006, 77, 111-130. [CrossRef]

62. Krajewski, P. Assessing change in a high-value landscape: Case study of the municipality of Sobotka, Poland. Pol. J. Environ. Stud. 2017, 26, 2603-2610. [CrossRef]

63. Vrščaj, B. Sprememba rabe zemljišč in kmetijstvo. Kazalci okolja v Sloveniji. Kmetijstvo. Ministry of the Environment and Spatial Planning of the Republic of Slovenia. Available online: http:/ /kazalci.arso.gov.si/ ?data=indicator\&ind_id=460 (accessed on 26 August 2018).

64. Ambrose-Oji, B.; Buijs, A.; Gerőházi, E.; Mattijssen, T.; Száraz, L.; Van der Jagt, A.; Hansen, R.; Rall, E.; Andersson, E.; Kronenberg, J.; Rolf, W. Innovative Governance for Urban Green Infrastructure: A Guide for Practitioners, GREEN SURGE project Deliverable 6.3; University of Copenhagen: Copenhagen, Denmark, 2017; Available online: https:/ / greensurge.eu/products/ (accessed on 27 August 2018).

65. McRoberts, R.E.; Chirici, G.; Winter, S.; Barbati, A.; Corona, P.; Marchetti, M.; Hauk, E.; Brändli, U.-B.; Beranova, J.; Rondeaux, J.; et al. Prospects for harmonized biodiversity assessments using national forest inventory data. In National Forest Inventories: Contributions to Forest Biodiversity Assessments, 1st ed.; Chirici, G., Winter, S., McRoberts, R.E., Eds.; Springer: Heidelberg, Germany, 2011; pp. 41-97, ISBN 978-94-007-0481-7.

66. Ritters, K.H.; Wickham, J.D.; Wade, T.G. Evaluating ecoregions for sampling and mapping land-cover patterns. Photogramm. Eng. Remote Sens. 2006, 72, 781-788. [CrossRef]

67. Dramstad, W.E.; Fjellstad, W.J.; Strand, G.H.; Mathiesen, H.F.; Engan, G.; Stokland, J.N. Development and implementation of the Norwegian monitoring programme for agricultural landscapes. J. Environ. Manag. 2002, 64, 49-63. [CrossRef]

68. Peterseil, J.; Wrbka, T.; Plutzar, C.; Schmitzberger, I.; Kiss, A.; Szerencsits, E.; Reiter, K.; Schneider, W.; Suppan, F.; Beissmann, H. Evaluating the ecological sustainability of Austrian agricultural landscapesThe SINUS approach. Land Use Policy 2004, 21, 307-320. [CrossRef]

69. Ståhl, G.; Allard, A.; Esseen, P.-A.; Glimskär, A.; Ringvall, A.; Svensson, J.; Sundquist, S.; Christensen, P.; Torell, Å.; Högström, M.; et al. National inventory of landscapes in Sweden (NILS)—Scope, design, and experiences from establishing a multiscale biodiversity monitoring system. Environ. Monit. Assess. 2011, 173, 579-595. [CrossRef] [PubMed]

70. Aune-Lundberg, L.; Strand, G.H. Comparison of variance estimation methods for use with two-dimensional systematic sampling of land use/land cover data. Environ. Model. Softw. 2014, 61, 87-97. [CrossRef] 
71. Stehman, S.V.; Sohl, T.L.; Loveland, T.R. Statistical sampling to characterize recent United States land-cover change. Remote Sens. Environ. 2003, 86, 517-529. [CrossRef]

72. Miličić, V.; Udovč, A. Uporabnost prostorskih podatkov kmetijskega sektorja za analize sprememb rabe kmetijskih zemljišč na primeru izbranega območja varovanja narave v Sloveniji. Geodetski Vestn. 2012, 56, 83-104. [CrossRef] 